\title{
The Japanese Asset Price Bubble: Evolvement and Consequences
}

\author{
Andre Tomfort ${ }^{1}$ \\ 'Professor for International Finance, Berlin School of Economics and Law, Germany \\ Email:nicemerlin2@web.de
}

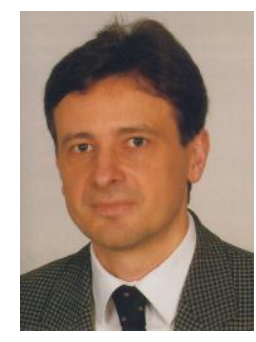

\begin{abstract}
Asset price bubbles and deep financial crises have occurred frequently during the past three decades. It began with the Japanese stock and housing market in the eighties, the technology bubble in stock markets before the millennium, and the housing bubble in the US and other countries, just to name a few. Such a degree of financial instability with extreme economic and social costs is unusual in economic history. To be able to find measures and their optimal timing to protect against these events a deeper understanding of the causes, evolvement and consequences of asset price bubbles is needed. The aim of this paper is to contribute to an improvement of that understanding by analyzing the historical case of the Japanese asset price bubble on the housing and stock market. The added value of such an analysis may come from the availability of today's research, experiences and econometric techniques.
\end{abstract}

Keywords: Japanese asset price bubble, Historical descriptive and empirical analysis, Eclectic valuation approach.

Citation | Andre Tomfort (2017). The Japanese Asset Price Bubble: Evolvement and Consequences. Asian Journal of Economics and Empirical Research, 4(2): 132-141.

History:

Received: 1 November 2017

Revised: 14 December 2017

Accepted: 20 December 2017

Published: 27 December 2017

Licensed: This work is licensed under a Creative Commons

Attribution 3.0 License (oc)

Publisher:Asian Online Journal Publishing Group
Funding: This study received no specific financial support.

Competing Interests: The authors declare that they have no conflict of interests.

Transparency: The authors confirm that the manuscript is an honest, accurate, and transparent account of the study was reported; that no vital features of the study have been omitted; and that any discrepancies from the study as planned have been explained.

study as planned have been explained.
Ethical: This study follows all ethical practices during writing.

\section{Contents}

1. Introduction

2. The Run Up to the Asset Price Bubble

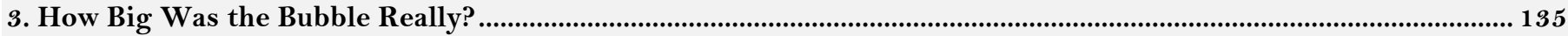

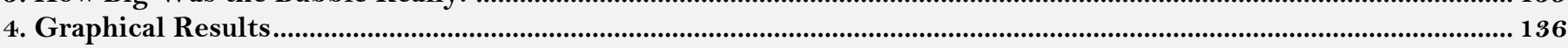

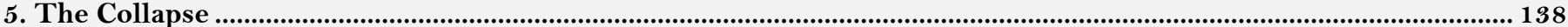

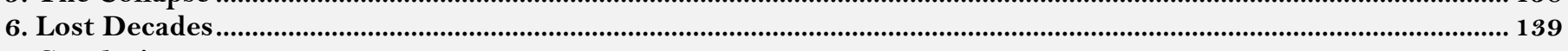

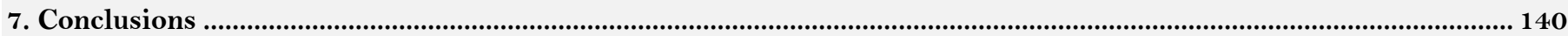

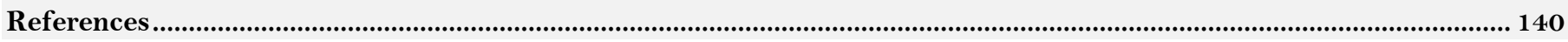




\section{Introduction}

In recent decades, sharp asset price increases with a following deep financial crisis happened within short frequencies (Bordo and Wheelock, 2007; Brunnermeier and Öhmke, 2013). These events had the typical characteristics of an asset price bubble such as an outstanding market valuation according to common valuation techniques, an euphoric investor base, a significantly stronger growth of private fixed investments and credit than the overall economy, which can be interpreted as an overinvestment and overleveraging of economic and financial activity. In the earlier stages of the bubble formation process often an expansionary monetary policy with low interest rates could have been observed as well as a deregulation of the financial sector (Tomfort, 2017). Such a bubble took place in Japan in the late eighties, in several Asian countries in the late nineties, in many stock markets before the millennium, and in the real estate market in the US and in parts of Europe up to 2007 (Schnabl and Hoffmann, 2007). Many of these bubbles have caused high social and financial costs and some of them have led to a long-lasting economic crisis. To be able to find measures and an optimal timing for their use to protect against these events a deeper understanding of the causes, evolvement and consequences of asset price bubbles is required. The aim of this paper is to contribute to an improvement of that understanding by analysing the historical case of the Japanese asset price bubble on the housing and stock market. The added value of such an analysis may come from the availability of today's research and experiences that includes recent bubble cases as well new econometric techniques. To assess a potential existence and the size of an asset price bubble an eclectic approach has been applied based on a simple discounted cash flow model, and a cointegration model that links asset prices with selected macroeconomic and financial variables. Furthermore, a gap of credit and private fixed investments to GDP were measured to recognize whether the Japanese economy was facing an overleveraging and overinvestment. They could have been responsible for the long-lasting and harmful deleveraging process Japan and other countries have suffered from. In contrast to most other studies in the field which are based on large sized cross sectional analysis, the chosen procedure is rather an inductive one for two reasons. The advantages compared to the crosscountry approaches are that a major bubble will be analysed and not simple market overreactions and the individual bubble analysis avoids certain losses of information that may happen in the aggregation process of a cross-country analysis.

The structure of the paper is as follows: It begins with a historical analysis of the time and the conditions before the asset price bubble started to evolve. This analysis is followed by a closer view on the business cycle, monetary and the development at the time when the asset price bubble was building up. In a third chapter it shall be tested whether really an asset price bubble has happened and what it's size was by running a comparison with estimated fundamental market values. The results were graphically shown together with the measured credit and investment gap versus GDP to assess to what extent an overleveraging and overinvestment of the Japanese economy had taken place. In chapter 4 the collapse of the financial system and the economy are analysed. A major focus was here on the role of monetary policy and financial acceleration processes and their interaction with the real economy. In the last chapter of this paper the reasons for the so called "lost decades" shall analysed with an assessment on the former fiscal and monetary policies.

\section{The Run Up to the Asset Price Bubble}

After the severe destruction of the Second World War, Nippon's economy began an extraordinary upward trend. Domestic companies were shielded from outside competition in the domestic market and abroad they quickly acquired market shares. Giant conglomerates formed, the so-called "keiretsu". One such "keiretsu" consisted, for example, of Mitsubishi Bank, Mitsubishi Heavy Industries and Mitsubishi Motors. The cross-shareholdings ensured mutual dependencies and stable long-term business relationships (Colombo, 2012). In the 1980s the companies, with the support of the government, increasingly focused on the technology and consumer electronics sectors (Glasmeier, 1988). Products were created which were cheap and competitive thanks to innovative and efficient production methods. The automotive sector was particularly successful. As a result, the country's current account surplus continued to rise, as did prosperity. The gross domestic product per capita exceeded that of many Western industrialized countries (Chang and Hirono, 1984). There was a high profit growth of companies and banks.

The Japanese financial system was primarily focused on banks, while capital markets tended to play a subordinate role. Numerous interdependencies and regulations ensured that the growth of the lending business was evenly distributed across all banks. This was described as a "convoy system". The interest on deposits was regulated and there was a strict separation between the credit, securities and insurance business. The banks were essentially supervised by the Ministry of Finance. In order to prevent financial institutions to surround these regulations, bonds were strictly regulated as well. In the seventies, the reform pressure on the financial system increased. Japanese companies began to become more and more internationalized by being active in foreign markets. In addition, the collapse of the Bretton Woods system led to fluctuations in the currencies between major trading partners so that companies needed new financial services, such as hedging transactions that took place on international markets (Hotta, 1992). The growing debt of the state played a further role, creating a large market for government bonds. As a result of the increase in bonds, the securities brokerage (Gesaki market) became popular, which enabled the players to get loans more easily and at short notice (Horiuchi, 1996). Markets for bearer securities were created as well. At the same time, the market for corporate bonds also picked up momentum and trade in options and futures contracts was expanded (Remolona, 1993). In the eighties, the financial sector was then consistently deregulated. Capital transactions with the rest of the world were fundamentally permitted by means of a continuous easing of the Foreign Exchange and Trade Control Act (Masunaga, 1996). In May 1984, the "YenDollar Agreement" was concluded, obliging the Japanese government to take comprehensive measures to open up the Japanese financial market. Money, bond and stock markets became accessible for foreigners. Tokyo became a large, international offshore market, which was freed from regulations and obligations. This liberalization wave revolutionized the investment and financing behaviour of Japanese companies. Bank loans lost their importance, and companies raised a larger portion of their required capital on financial market. Shares, bonds and money market paper gained importance. In a study, it was found that the monetary transmission in the 1980s had become 
noticeably more dependent on the financial markets than before (Hoffmaister and Schinasi, 1994). Rising land and share prices increased the collateral that banks can dispose of if a customer becomes insolvent. This made it easier for banks to trust their borrowers and to offer loans. A reciprocal process of rising prices of land and stocks on the one hand, and lending on the other, started. Loans were easy to get and the risk of investment projects grew (Hoffmaister and Schinasi, 1994). For banks, competition intensified with lower interest and profit margins. They responded by investing more in riskier projects where higher yields could be achieved. The risks in their credit portfolios increased. In addition, Japanese financial institutions turned more to private households and the real estate sector, as well as small and medium-sized businesses, in order to serve new markets (Heinz and Manzenreiter, 2003). This created the prerequisites for a speculative bubble. It was easy to receive money and loans, and the risk tolerance of all parties involved was high. The mood indicators for industry and consumers were positive (Uemura, 2009).

\subsection{Business Cycle, Monetary Policy and Asset Prices}

In the middle of the 1980s, the Americans put pressure: While Japan's current account surplus was growing steadily the deficit in the USA increased correspondingly (Uemura, 2009). Political tensions between the two countries came up. The Americans urged the Japanese to open their business for foreigners even more and stimulate their economy vigorously. In 1985 the Plaza Agreement was convened, in which the Japanese committed themselves to stimulate their economy to boost imports. Monetary policy now became much more expansionary (Okina et al., 2000). When the economy slowed down a short time later as a result of a strong appreciation of the yen against the dollar after the Plaza Agreement, monetary and fiscal stimulation efforts became even more supportive. Interest rates fell from $5 \%$ to $2 \%$ in 1988 . Debt from the private sector expanded strongly, which was also due to the margin pressure in the banking sector as a result of the described deregulation. The growth of loans was significantly higher than GDP over the whole of the eighties. The debt of private households multiplied sevenfold from 1979 (9 trillion yen) to 67 trillion yen in 1991. The volume of real estate loans also doubled between 1985 and 1989 (Weingarten, 2010). It came to a run on real estate. Land and property prices doubled, even quadrupling in metropolitan areas such as Tokyo and Osaka (Hoffmaister and Schinasi, 1994). Shares tripled in value between 1985 and 1989. ${ }^{1}$ The Nikkei 225 Index rose from 11,542 points in December 1984 to 39,000 points five years later. At that time, Nikkei made a third of the world's equity capitalization (Weingarten, 2010). Two Ponzi Schemes played a major role for the spectacular rise of asset prices: Speculative gains could be booked as a gain in company's balance sheet (Colombo, 2012). As a result, rising share prices led to higher profits, which in turn led to rising share prices. The second scheme was based on the fact that rising prices in the equity and real estate markets aroused each other: a company that owned land rose in value as land prices increased so that also stock prices moved up. The higher share price enabled the companies to get fresh capital through the issuance of new shares in order to purchase land and buildings (Ito and Iwaisako, 1995). In both asset markets, strong herd behaviour was observed. Authors who had empirically investigated the relationship between land and stock markets found that land prices were strongly influenced by past land and stock prices (Ito and Iwaisako, 1995). The players in the real estate sector were particularly inclined to continue the latest trends into the future. A certain autocorrelation could also be proved in the case of share prices with past share and land prices, which, however, was markedly less pronounced. Herd behaviour usually occurs persistently when economic conditions have remained stable over a long period of time (Valev, 1996). This includes a long-term economic upswing as well as an established positive price trend in the market. Under these circumstances, the information content of past purchase decisions by other actors seems to be particularly valuable and reliable. Herd behaviour, however, is problematic for two reasons. It promotes exaggerations on the market and important private information is lost to the market's information pool because agents simply copy the decisions of each other instead of using their own information. This reduces the efficiency of the market and the pricing reflects to a lesser extent the fundamental value of the market. There is a lot of evidence that this was the case in Japan at the time as can be seen on Figure 1. The autocorrelation of housing prices - and thus the assumed herd behaviour - was particularly pronounced in the time span from 1986 to 1990 - the most dynamic stage of the bubble formation ${ }^{2}$. The autocorrelation was measured on the basis of a rolling twelve-month average.

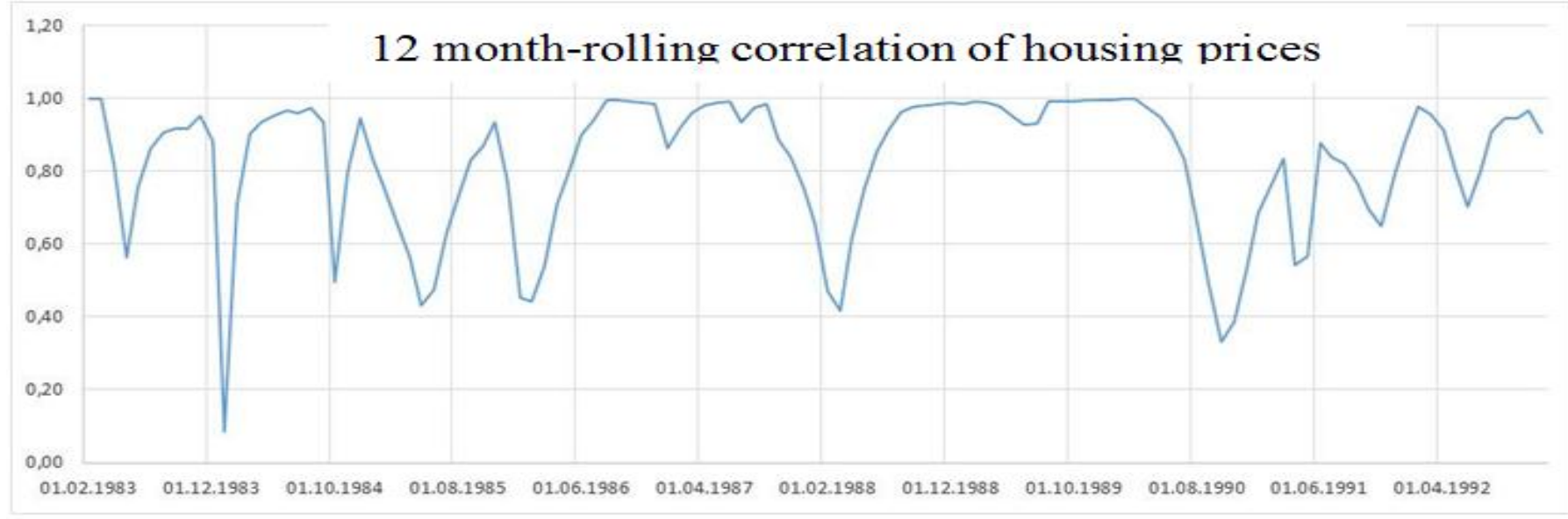

Figure-1. The autocorrelation on the real estate market

Source: Data stream and own calculations

Autocorrelation and the boom land and housing prices were supported by the tax legislation and state regulations at that time. Taxes on land property were very low during this period, while taxes on the sale of land

Time after the Plaza-Accord

${ }^{2}$ See chapter 3 
and capital gains were high. The inheritance tax on land was comparatively low so that land was an attractive heritage As a result landowners had very little incentive to sell their land - despite rising prices. At the same time interest on loans could be used to reduce income taxes. Against this backdrop, there was an artificial scarcity of land supply, which had accelerated the price increase (Okina et al., 2000).

The mood on the markets became euphoric. Not even institutional investors at that time believed that the Japanese market was overvalued. $82 \%$ of all companies, private households and financial institutions estimated the future positively (Shiller et al., 1992) just before the crash happened in 1990. They bought more and more stocks and real estate and financed them through loans. This resulted in a dangerous interrelationship between rising prices and risk tolerance that ended up not only in extreme market valuations, but also heavily indebted the entire financial system, making it highly vulnerable to higher interest rates or corrections of market values. This process is typical for the development of asset price bubbles. If prices on the real estate or equity market have risen over a longer period, as has been the case in Japan, investors are increasingly able to record book gains in their portfolios. These book gains shift the risk appetite of investors towards riskier transactions because - psychologically - they are perceived as gifts for which investors had nothing to do. If these gains are lost again, the loss pain is comparatively small. This risk perception has been demonstrated in a series of experimental psychological studies and finds its precipitation in the "dynamic prospect theory" (Barberis et al., 2001).

\section{How Big Was the Bubble Really?}

A first problem analysing asset price bubbles is that there is no commonly accepted view what an asset price bubble is. Often quoted is the definition of Kindleberger: an asset price bubble is as a sharp rise in the price of an asset or range of assets in a continuous process, with the initial rise generating expectations of further rises and attracting new buyers - generally speculators, interested in profits from trading in the assets rather than in its use as earning capacity (Kindleberger, 1978). Another widely recognized definition characterizes an asset price bubble as an explosive and isometric deviation of the market price of an asset from its fundamental value, with the possibility of a sudden and significant reverse correction (Kubicova and Komarek, 2011). Thereby, the fundamental value is characterized by the net present value of the asset. Shiller states, that a bubble is a situation in which temporarily high prices are sustained largely by investors' enthusiasm rather than by consistent estimation of real value (Shiller, 2000). What can be drawn out of these definitions? Asset price bubbles contain a strong speculative element. The fundamental value will be at least partially neglected by investors, and a strong market correction has to be expected once the bubble bursts. In addition, the process of the bubble formation is explosive and non-linear. These definitions refer to extreme market events as they shall be investigated in this paper. Borio and Lowe (2002) run an asset bubble study for 34 countries for the years 1960-1999. According to them, asset price bubbles move along with an investment boom in the real economy as well as strong credit expansion and a high financial leverage in the banking and corporate sector. This combination seemed to be particularly dangerous for the stability of a financial system. The two authors confirm in their study that indications exist which can be used to detect or recognize asset price bubbles. These characterisations of an asset price bubble and the results from Borio and Lowe are the basis for the following empirical analysis.

It begins with a simple discounted cash flow model to assess the fundamental value of the Japanese housing and stock market. After that, an autoregressive distributed lag model for cointegration has been introduced to test for a long-term equilibrium between financial prices of the two markets and several macroeconomic or financial indicators. Long-term variation coefficients have been derived if cointegration was found and been used to calculate another fundamental value. The differences of the market values from the two independent fundamental values can be interpreted as an asset price bubble - if they were found to be extraordinary large. In a further empirical analysis the credit and investment-to-GDP growth will be compared to investigate whether the bubble process in financial markets is moving along with a leveraging and investment boom in the real economy. If this was found, a truly and devastating asset price bubble is at place.

\subsection{The Discounted Cash Flow Model for Stock and Housing Markets}

The value of real estate or stocks can be estimated by a simple discounting the future expected rents/dividends.

$$
\text { (1) } \quad P_{h / s}=\frac{\text { Rents / Dividends }}{i}
$$

$\mathrm{P}_{\mathrm{h} / \mathrm{s}}$ stands for the estimated fundamental value of a house or stock, and $\mathrm{i}$ - the discount rate - for representative interest or mortgage rates. $\mathrm{P}_{\mathrm{h} / \mathrm{s}}$ stands for the price level of the housing or stock market. In the academic discussion, it was not undisputed whether cointegration based present value estimates can be used (Campell and Shiller, 1987). Therefore, the standard DCF-approach was applied here. Its aim was to measure the size of a possible market overvaluation in percentage terms. Of course, this DCF-approach is linked to several important weaknesses. Rents or dividends may artificially be boosted by the bubble formation process so that calculated values are underestimating the true overvaluation of the market. In addition, market prices are forwardlooking while current cash flows are used. This time gap may also lead to wrong conclusions. Despite these limitations, the DCF-approach belongs to the most reliable valuation measures available.

\subsection{Autoregressive Distributed Lag Models and Cointegration}

The aim of this methodology is to find macroeconomic or financial variables that form a long-term equilibrium path with stock and housing market prices. That path can be used to calculate another fundamental value for stock and housing market prices. Several cointegration approaches could be applied in this context but most of them would require that the variables included have to have the same order of integration. This would exclude a lot of potential variables and limit the quality of the model substantially. Therefore, an alternative cointegrating technique is used - the autoregressive distributed lag (ARDL) approach. This approach allows the use of variables with different orders of integration (Pesaran and Shin, 1999). The distribution of F-statistics is non-standard irrespective of the integration order of the included variables. Two sets of critical values are provided, one in which 
all variables are assumed to be of integration order one and another in which all variables are assumed to be of zero order. These two sets form a band covering all possible classifications of the variables in terms of their integration order. If the computed F-statistic is above the values of this band, the analysis can continue without knowing the order of integration of the underlying variables. If it falls within the band than a distinction of the variables becomes necessary. The ARDL approach provides a linear error-correction model to test the significance of the underlying variables and their cointegration. In addition, long-run coefficients based on ARDL models selected by AIC and SBC criteria can be estimated to use them for the calculation of a macroeconomic based fundamental value for housing and stock prices.

According to economic pretesting for the Japanese housing market prices (JPHP) the unemployment rate (UR), business failures (BF), and business confidence (BC) could be cointegrated based on an integration order of one. The equation takes the following form:

$$
\text { (2) } J P H P=\alpha_{o}+\alpha_{1} U R+\alpha_{2} B F+\alpha_{3} B C+\mu_{t}
$$

The error correction version of the ARDL model is as follows:

$$
\begin{aligned}
& \Delta J P H P_{t}=\alpha_{o}+\sum_{i=1}^{n} \alpha_{1 i} \Delta J P H P_{t-i}+\sum_{i=1}^{n} \alpha_{1 i} \Delta U R_{t-i}+\sum_{i=1}^{n} \alpha_{1 i} \Delta B F_{t-i} \\
& +\sum_{i=1}^{n} \alpha_{3 i} \Delta B C_{t-i}+\alpha_{4 i} J P H P_{t-1}+\alpha_{5 i} U R_{t-1}+\alpha_{6 i} B F_{t-1}+\alpha_{6 i} B C_{t-1}+\mu_{t}
\end{aligned}
$$

The model for the Japanese housing market was calculated by using monthly data from M1 1980 to M12 1992 . The data was transformed into logarithms except for interest rates. The Augmented Dickey-Fuller Test showed that all variables were of integration order zero or one. Only Japanese housing prices varied between order one and two. For simplicity it was assumed that they were also of integration order one.

For the Japanese stock market a cointegration based model was not found.

\subsubsection{The ARDL Model and Its Long-Run Coefficients}

The unemployment rate, the amount of business failures, and business confidence were statistically significant and cointegrated with housing prices. The economic foundations for these variables are as follows: The level of unemployment is affecting disposable income to finance housing. Business failures had an impact on the demand for housing since corporations were heavily invested in the real estate sector at that time. Another channel of influence was that the willingness of banks to finance housing activities of corporations was dependent on the amount of business failures. Business sentiment influenced the readiness of corporations to invest in the housing market. The ARDL showed the following results for the error correction version of the model.

Table-1. ARDL (2,0,0,0) Error Correction Presentation

\begin{tabular}{l|l|l|l|l|l}
\hline Est. Variable & $0.574 * \mathrm{dJPHP}_{\mathrm{t}-1}$ & $-0.197 * \mathrm{dUR}$ & $0.067 * \mathrm{dBF}$ & $0.419 * \mathrm{dBC}$ & $-0.135 * \mathrm{ec}_{\mathrm{t}-1}$ \\
\hline STDE & 0.0739 & -0.0058 & -0.0351 & 0.2071 & 0.0273 \\
\hline T-R. & $(7.76)$ & $(-3.39)$ & $(-2.52)$ & $(2.02)$ & $(-4.94)$ \\
\hline Prob. & $(0.00)$ & $(0.001)$ & $(0.013)$ & $(0.045)$ & $(0.00)$ \\
\hline
\end{tabular}

\begin{tabular}{|c|c|}
\hline R-Squared $=0.447$ & R-Bar-Squared $=0.422$ \\
\hline F-Statistics $=17.63(0.00)$ & DW-Statistics $=1.726$ \\
\hline \multirow{2}{*}{\multicolumn{2}{|c|}{$\begin{array}{l}\text { F-statistic: } 5.479 \\
\text { 95\% Low. Bound / 95\% Up. Bound / 90\% Low. Bound / 90\% Up. Bound }\end{array}$}} \\
\hline & \\
\hline $3.3202 \quad 4.433$ & $74 \quad 3.830$ \\
\hline
\end{tabular}

Source: Own calculations

Table-2. Estimation \& Diagnostic Statistics

Table 1 show that the included variables were statistically significant according to their t-ratios. All three variables had the theoretically expected sign as well as the error correction term that was highly significant and had a negative variation coefficient. It was -0.135 suggesting that $13.5 \%$ of the deviation from equilibrium that may result from a shock will disappear after a month. The assumption of cointegration was proven by the $\mathrm{F}$-statistic value of 5.479 that was above the critical $95 \%$ and $90 \%$ upper bound level. The R-Squared was indicating high correlation, although it might have been somewhat distorted from the autocorrelation of residuals as hinted by the Durbin-Watson coefficient. The next step is to derive the long run coefficients out of this ARDL model as presented in Table 3:

Table-3. Long-run coefficient estimates and diagnostics

\begin{tabular}{c|c|c|c}
\hline Constant & UR & BF & BC \\
\hline 0.01405 & -0.146 & -0.496 & 3.105 \\
$(3.72)$ & $(-3.23)$ & $(-3.20)$ & $(2.39)$ \\
\hline
\end{tabular}

The upper row shows the results for the long-term variation coefficients of the explanatory variables. The values in brackets are the t-statistics. All variables have the theoretically expected signs and are significant as in the error-correction version. These values can now be used to derive a cointegration based fundamental value for the Japanese housing market. The outcome will be presented in the following graphs.

\section{Graphical Results}

For the assessment of the valuation models and the investment as well as the credit gap calculations, a ten-year rolling window for the assessed time series was introduced. From historical experience it is known that the bubble formation process lasts about that time so this time window seems to be the most appropriate. 


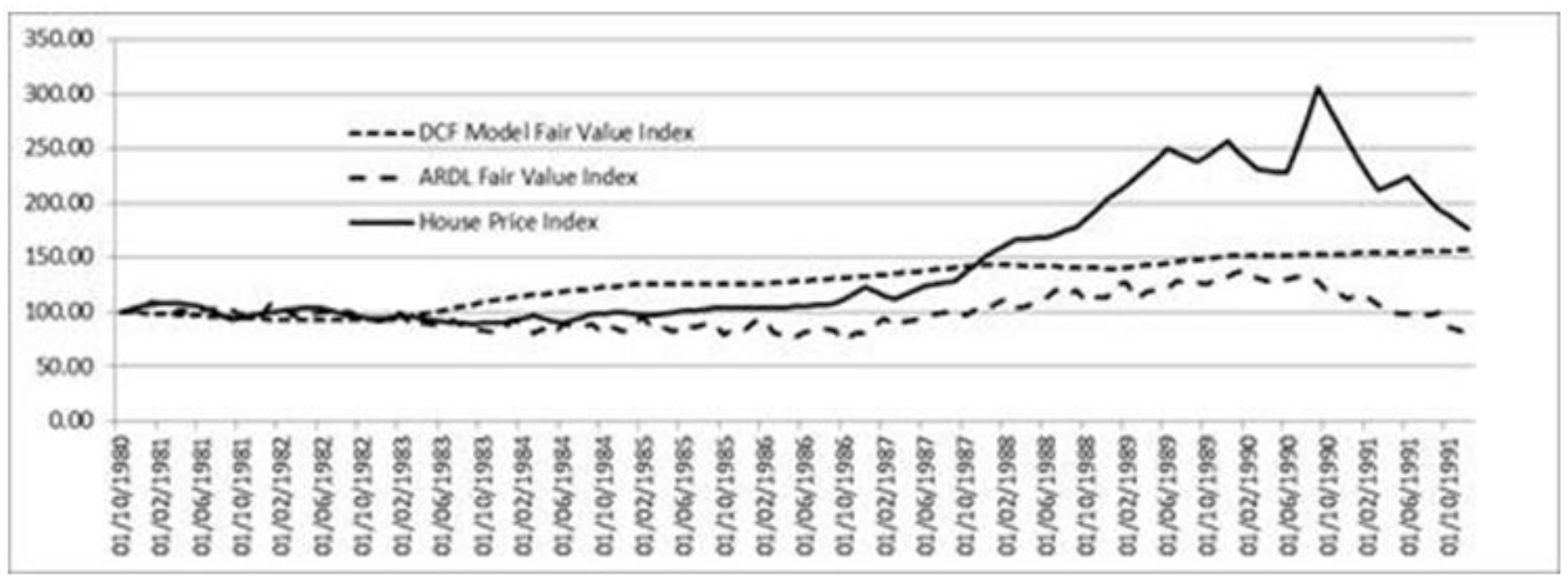

Source: Datastrem and own calculations

Figure-2. Japanese Housing Market \& ARDL long-run coefficient and DCF

The dotted line represents the discounted cash flow model results, the slashed line the ARDL-estimates, the continuous line the housing market. Both fair value model estimates indicated that the housing market was overvalued by a level of around 100\%. The price bubble entered its final and explosive phase from 1988 onwards when market prices decoupled from the estimated values. The DCF- results showed a higher fair value than the ARDL-model. Since the two largely independent approaches pointed towards a highly overvalued housing market, one may conclude that an asset price bubble was at place. While this calculation was based upon an average countrywide house price index, prices in large cities such as Tokyo or Osaka moved up four times as much. To a certain extent one may say that the degree of the asset price bubble was rather understated by the used data.

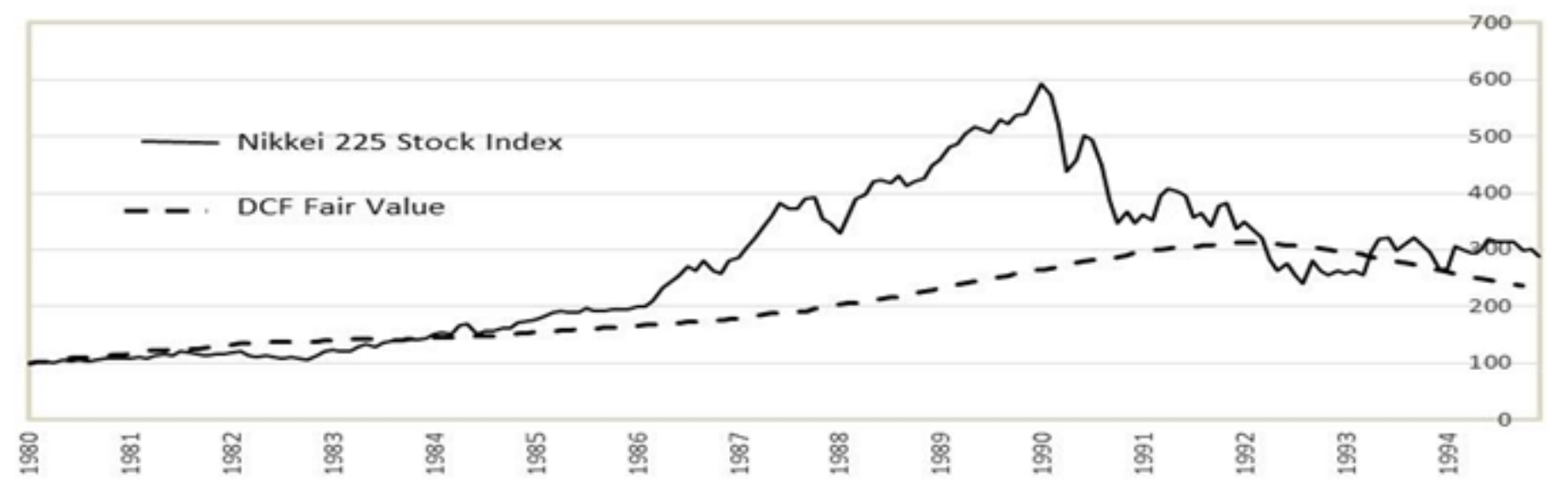

Source: Datastream and own calculations

Figure-3. Japanese Stock Market and DCF-fair value estimates

The dotted line represents the discounted cash flow model, and the continuous line the stock market. The DCF-fair value indicated that the stock market was overvalued by more than $100 \%$. Probably this calculation is underestimating the degree of overvaluation because the underlying cash flows are also likely to be inflated in that period. This is one of the typical disadvantages of the DCF-approach. Nevertheless, also for the stock market a fair conclusion is that an asset price bubble took place from 1987 onwards until the early months of 1990. For the stock market it can be said that it entered its final and explosive phase already in from 1986 onwards when market prices decoupled from the estimated fair values.

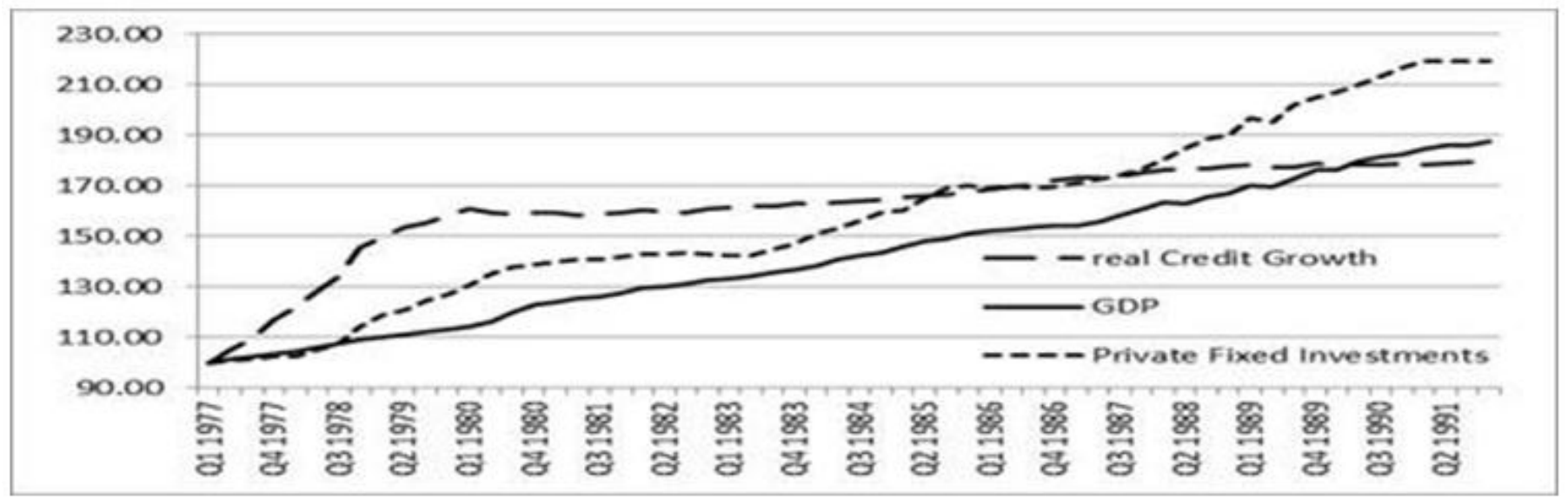

Source: Datastream and own calculations

The assessment that Japan was in a true asset price bubble as described in the beginning of this paper could be seen by the growing gaps of credit and investment relative to GDP. The continuous line represents GDP, the slashed line credit expansion, and the dotted line investments. Credit demand began to accelerate sharply in the late seventies and stimulated investments in housing and business equipment. This move was due to the 
deregulation of the financial sector that happened at that time. Interest rates were still at levels of $6 \%$ or higher and not supportive in the early stage of the considered time period. The credit gap became less pronounced in the following years despite falling interest rates. However, it was effective until the bubble burst and contributed to its development. One would expect that credit is expanding particularly fast in the last three years of the bubble when buying assets on margin seems to be very lucrative. This was not the case here. However, the large early gap was sufficient to finance the bubble in housing and stocks as well as the overinvestment in the economy. Once a portion of the investment boom turns out to be unprofitable - which is usually the case when a recession sets in - a financial deleveraging will be forced in the private, corporate and banking sector. The larger the rise of the credit and investment boom was the deeper and longer the deleveraging process that follows. From August 1988 onwards all of the four bubble measures in this paper were above the proposed threshold value of the 10 year average plus half the standard deviation. The central bank and the government would have had two years to tackle the growing bubble.

\section{The Collapse}

The Japanese central bank became increasingly concerned about the rising prices of goods, services and financial assets in 1989. The strong growth of the economy for several years finally was felt in terms of inflation. Towards the end of the 1980s, the economy hit its capacity limits. After ending the recession at the end of 1986, the economy continued to expand for four years and three months until February 1991. This was the longest economic expansion since the late 1960s. During this period, real GDP grew on average with an annual rate of $5.5 \%$ and industrial production with $7.2 \%$. The output gap was positive in 1987 and continued to grow towards the end of 1989 (Okina et al., 2000). So the economy grew significantly above potential. Inflation had remained moderate for quite some time but in 1989 a noticeable increase happened. In November 1990 it accelerated to 3\%. At that time, the price bubble on the financial markets had long been fully developed and the crash had started. The inflation risks were only visible when the price bubble had burst. This outcome is clearly contradicting the Jackson Hole consensus among central bankers (Bernanke and Gertler, 2001) which is claiming that as long as inflation is tame also the economy and financial markets are in equilibrium. It was striking that rents decoupled from the sharp price rise of properties to a large extent. They increased continuously, but at a moderate pace (Shimizu and Watanabe, 2010). This contributed significantly to the fact that inflation remained tamed for a long time. One reason for this phenomenon could have been the existence of long-term contracts between tenants and landlords, whose changes are also limited by state regulations.

From May 1989 onwards, the central bank began to increase interest rates gradually. Other central banks in the western world had already done so - but not as strongly as in Japan. Until August 1990, the Japanese raised their interest rates from $2.5 \%$ to $6 \%$. These interest rate increases hit a high level of private sector debt, which in the second half of the 1980s had grown extraordinarily strongly both in absolute terms and relative to the GDP (Hoffmaister and Schinasi, 1994). The balance sheets of the financial sector ballooned accordingly. Nine of the ten largest banks in the world came from Japan (Patrick, 1998). The high level of debt and the inflated balances of financial institutions made the economy particularly vulnerable to the effects of a restrictive monetary policy. Initially, the first interest rates of the central bank remained ineffective - the economy and financial markets continued to flourish. Toward the end of the year the sentiment suddenly changed and the stock market collapsed. The "Zaitech effect" now turned into its opposite - the profits of companies shrank dramatically and the prices on financial markets followed. This also led to a rise in risk premiums for the granting of loans. A number of investment projects, which were launched and designed in the previous years, now turned out to be unprofitable (Hoffmann and Schnabl, 2009). The growth rate of the return on equity was already negative in 1990. The overall economic demand weakened and the increased interest rates dampened investment and speculation. An intensifying downward spiral of falling prices on the stock market, a worsening of the mood and a declining demand for goods and services was the consequence. The real estate market, on the other hand, remained remarkably resistant (Shimizu and Watanabe, 2010). Despite the growing worries and risks, prices rose even slightly. As a result, private households were still spared the crisis to some extent.

However, about one year later, the boom in the real estate market also ended. First, prices for commercial real estate broke down. The same happened to the price of land in the metropolitan areas, especially in Tokyo. The delay of the real estate market reaction was due to the fact that current real estate and land prices do not really reflect the actual situation on the market, but move with a time-lag. This is due to a lack of transparency. On the stock market, prices are quoted every second, provided the market is open. There is also a relatively high number of transactions per trading day. This is completely different on the real estate market. Unlike stocks, real estate is not homogenous at first - no real estate is exactly the same. Then far less real estate is traded - in some submarkets sometimes not for weeks. This makes the market value far more obscure and many owners are only willing to accept a fallen price level with a greater delay. Once also housing prices started to fall it became increasingly difficult for companies to get financing for new housing, and financing became also considerably more expensive because of increased risk premiums. New offices and factories were no longer needed. Once private properties also lost value, the financial situation of private households fell into disrepair. Their collateral fell to levels below their debt, so loans from banks were terminated earlier or not extended. In the same way, corporations run into financial troubles. The crisis took full steam. After the bubble burst, the Nikkei fell from 40,000 points in December 1989 to below 8,000 points in 1999. Land prices lost 80 of their value between 1991 and 1998. Unemployment rose steadily from $2.1 \%$ in 1998 to $4.7 \%$ in 2000. For Japanese conditions this increase was enormous and shocked the Japanese who were used to job security. Their social systems found this development largely unprepared. This resulted in a veritable and long-lasting demand crisis. As soon as the first crash wave had passed between 1989 and 1991, the country's past optimism changed into an excessive pessimism, which accelerated the decline in financial market prices. For example, the consumer sentiment index fell from over 50 points in December 1989 to just 36 points in 1993. This was also supported by the onset of herd behaviour on the negative side. Assets were sold because all did and because the long lasting capital losses triggered panic. In addition, companies were forced to adjust their balance sheets and reduce their debt levels. Furthermore, the 
company's inflated capital stock had to be reduced (Yoshino et al., 2012). This led to further losses in investment demand and accelerated the decline in financial market prices. There were bankruptcies and defaults encumbering bank balances, which triggered a long-lasting negative financial acceleration. All this turned into high risk premiums for new loans and in the equity market as well as into banks' extremely low willingness to lend. The demand for investments fell dramatically, the decline in financial market prices accelerated. Unusual high levels of bankruptcies resulted in a long-lasting credit crunch. The fact that banks had been so reliant on land and real estate on their loans made a significant contribution to the long-lasting balance-sheet problems. Their equity melted and hidden reserves became hidden burdens. A total of 170 financial institutions had to file for bankruptcy (Patrick, 1998).

\section{Lost Decades}

All this was followed by the "Lost Decades". Slow or no growth and deflation were their hallmarks. Unprofitable, heavily indebted banks and companies had been artificially kept alive through state subsidies and a zero-percent-interest-rate-policy. Measures that should prevent a hard landing of the economy in the short term prevented a real clean-up of the problems over the long run (Weingarten, 2010). The creeping downward trend did not end. In 2004, the property market in Tokyo was just 10\% of its value, which was paid for in 1990. Japanese equities were still trading for a quarter compared to the boom year. GDP growth was only $1.1 \%$ on average in the period 1992-200, compared to $3.8 \%$ in the period between 1974 and 1991. In the late 1990s a creeping deflation began in Japan. This was also due to falling nominal wages, which was not observed in any other OECD-country. Unaccustomed unemployment was a major cause in this regard (Heinz and Manzenreiter, 2003). Despite massive support measures through monetary and fiscal policy, the Japanese economy was still unable to recover sustainably. The monetary policy was in a liquidity trap due to the described problems in the financial sector. A number of economists were of the opinion that the Japanese government should have encouraged companies and banks to write down unprofitable investments, clean up balance sheets and continuously reduce debt (Okina, 1999). Instead, the government and central bank delayed this process of adjustment by ensuring that market prices remained artificially high, impacted savings with negative incentives, and stimulated consumer demand through short-term spending programs. This exceedingly interventionist policy had no success. Between 1990 and 2000, Japan experienced ten such government stimulus programs that cost more than 100 trillion yen (Weingarten, 2010). In addition, aid for the banking sector and credit guarantees for companies were provided. All this led to a massive increase in the national debt, which in 2000 amounted to more than $100 \%$ of GDP without the country being able to free itself from the crisis. This was still the case for 2010. Only the national debt had now doubled to $200 \%$ of GDP. An important reason among others for this negative development may have been the rampant corruption. Loans were not always awarded according to economic criteria, but because of political relations. The result was a large number of failed investment projects. The main beneficiary of government expenditure programs was the construction industry, which traditionally belonged to the supporters of the governing LDP (Kawata, 2011). From an economic point of view, this has led to a tying of resources into sectors that could have been used in other sectors much more efficiently and more profitably. Companies that did not have such political relations found it even more difficult to get money, because the few loans that banks still offered, were given to those companies, to which the state's programs promised a better future in the short term. In this way it lasted until the turn of the millennium, before the profitability of capital began to recover slowly.

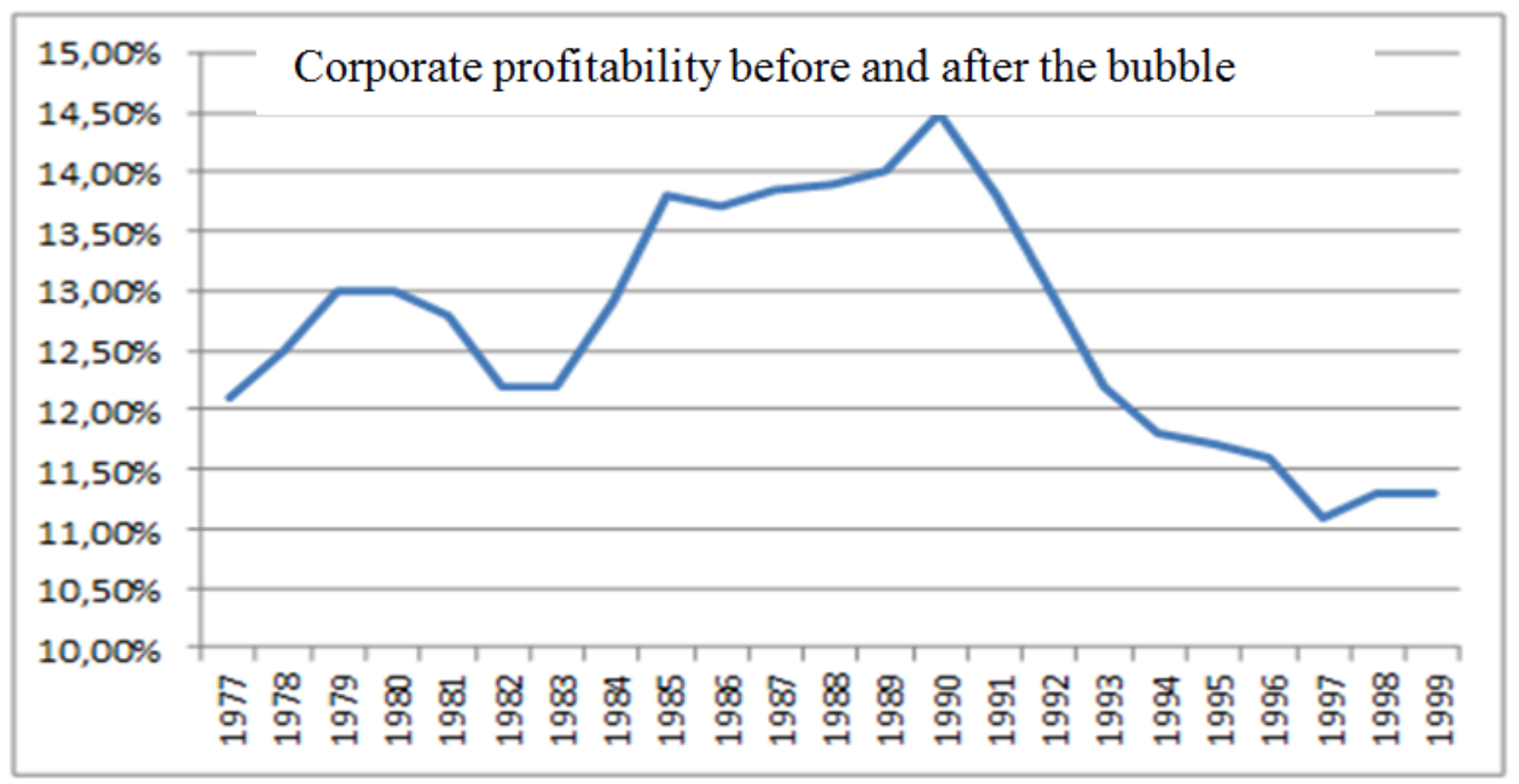

Source: Fukao et al. (2014)

Figure-5. Development of capital profitability

As can be seen in the next graph, credit institutions did not manage to curb the increase in bad loans in their balance sheets by the turn of the millennium. It amounted to about $7 \%$ of GDP. However, even this figure was under suspicion, to have been beautified (Hanazaki and Horiuchi, 2002). Mainly responsible for the length of the credit crisis was the long-lasting decline in land prices and the ever-new lending to debtors threatened with bankruptcy in order to prevent the final depreciation of bad loans. 


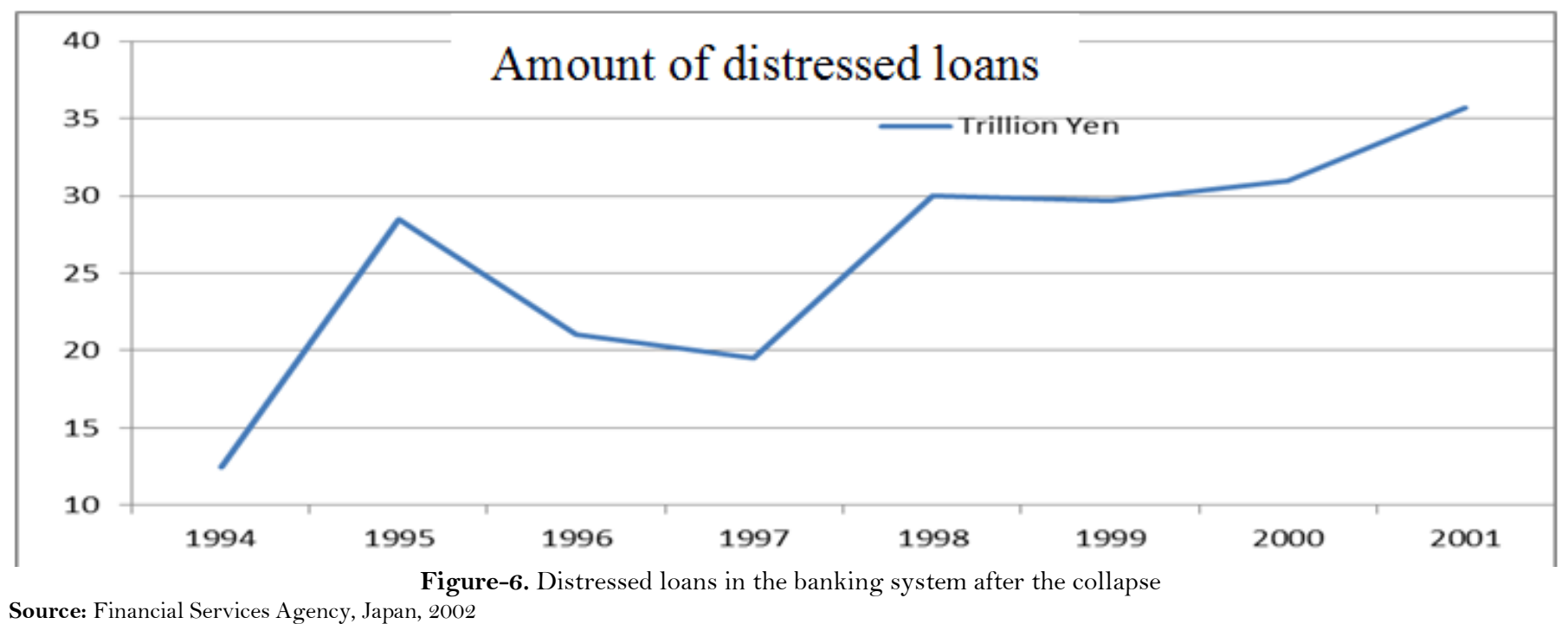

Apart from the unstoppable rise in government debt, Japan's economic policy has two further negative consequences: banks and companies that generate little or no income from their capital are artificially kept alive by state aid and economic stimulus programs. As a result, the economy is permanently deprived of part of its growth potential. Moreover, the Japanese central bank's unceasing supply of money jeopardizes the stability of other countries. Capital seeks its way to higher yields. If these are not sufficiently found in Japan, then it flows abroad. For example, some economists attribute the financial crisis of a number of Asian economies to the flow of money from Japan towards the end of the 1990s (Hoffmann and Schnabl, 2009). And even today, the stream of Japanese money wafts through the world financial system and could contribute to the emergence of a new price bubble in other countries. To get away from this path of economic policy has become extremely difficult after such a long time. Although the country's debt has risen to more than 200\% of GDP it "only" has to pay 25\% of its tax revenues for interest rates (Satyajit, 2013) because of interest rates on government debt being kept so low. If the interest rate were to rise to $4 \%$, which corresponds to the long-term historical average of the industrialized countries, the country would have to spend its whole national budget on the interest rate service alone.

\section{Conclusions}

The Japanese long-lasting financial crises had been caused by major asset price bubbles in the real estate and stock market. The applied two valuation approaches, which were to a large extent independent of each other, supported this assessment for the housing market and the DCF-approach for the stock market alone. The reasons for the evolvement of these bubbles had been quite typical according to what can be learnt from economic history. A long-term economic upswing in combination with an increasingly expansionary monetary policy and a far reaching deregulation of the financial sector laid the ground for it. Tax laws played an additional role by reducing the sell side of the housing market. During the bubble formation phase two Ponzi processes were at work which accelerated the boom on the markets. If such Ponzi processes can be observed together with an overleveraging of the economy and patterns of overinvestment - as it was the case in Japan - governments, central banks and investors should react by strengthening the financial system, increasing interest rates and reducing investment risks. The collapse set in once the Bank of Japan was forced to raise interest rates due to increasing inflationary pressures and concerns about extreme market valuations. Also this was a typical pattern from a historical prospective. The Jackson Hole consensus among central bankers that the economy as well as financial markets are in equilibrium as long as inflation remains stable had been proven wrong as in many other historical cases. Inflation is a lagging economic indicator and financial markets are forward-looking so when inflation finally becomes visible it is too late because the bubble has already built up. In addition, in a world of open and globalised economies it takes a longer time before an economy hits capacity limits. Regarding the economic policy after the burst of the bubble it became clear, that expansionary fiscal and monetary policies cannot replace the elimination of structural imbalances such as the write-downs of bad loans or overinvestments in the real economy. If these structural measures are avoided because decision-makers are afraid of short-term economic and social costs than short-term stabilisation policies may become a long-term burden for the recovery of the economy. The long time it took before the corporate sector could overcome the downturn of its profitability or the banking sector its bad loan problem were clear indications for that.

\section{References}

Barberis, N., M. Huang and T. Santos, 2001. Prospect theory and asset prices. Quarterly Journal of Economics, 116(1): 1-53. View at Google Scholar

Bernanke, B. and M. Gertler, 2001. Should central banks respond to movements in asset prices. American Economic Review, 91(2): 253-257. View at Google Scholar | View at Publisher

Bordo, M. and D. Wheelock, 2007. Stock market booms and monetary policy in the 20th century. Fed of St. Lewis Review, 89(2): 91-118. View at Google Scholar

Borio, C. and P. Lowe, 2002. Asset prices, financial and monetary stability: Exploring the nexus. BIS Working Paper, No. 114.

Brunnermeier, M.K. and M. Öhmke, 2013. Bubbles, financial crisis, and systematic risk. Amsterdam: Handbook of the Economics of Finance, Elesevier. Campell, J. and R.J. Shiller, 1987. Cointegration and tests of present value models. Journal of Political Economy, 95(5): 1062-1088. View at
Google Scholar | View at Publisher

Chang, M.K. and R. Hirono, 1984. ASEAN-Japan industrial cooperation. An overview. Singapore: Institute of Southeast Asian Studies.

Colombo, J., 2012. Japan`s bubble economy of the 1980s, Paper for the San José University, 4th June.

Fukao, K., K. Ikeuchi, Y. Kim, H. Kwon, T. Makino and M. Takizawa, 2014. Lessons from Japan`s secular stagnation. RIETI Discussion Paper Series, 15-E-124. 
Glasmeier, A.K., 1988. The Japanese technopolis program: High-tech development strategy or industrial disguise. International Journal of Urban and Regional Research, 12(2): 268-284. View at Google Scholar $\mid$ View at Publisher

Hanazaki, M. and A. Horiuchi, 2002. A review of Japan's bank crisis from the governance perspective. Center for Economic Institutions Working Paper No. 2002-3.

Heinz, R. and W. Manzenreiter, 2003. Finanzkrise im Zentrum. Der Fall Japan. In: Geld Macht Krise.Finanzmärkte und neoliberale Gesellschaft. 1st Ed. Wien.

Hoffmaister, A.W. and G. Schinasi, 1994. Asset prices, financial liberalization and the process of inflation in Japan. IMF Working Paper, No. $94 / 153$.

Hoffmann, A. and G. Schnabl, 2009. A vicious cycle of manias, bursting bubbles and asymmetric policy reponses - an overinvestment view. MPRA Paper, No. 18532.

Horiuchi, A., 1996. An evaluation of Japanese financial liberalization: A case study of corporate bond markets. In: Financial Deregulation and Integration in East Asia. NBER EASE-Publication, 5: 167-192

Hotta, K., 1992. Deregulation of the Japanese financial markets and the role of Japanese banks. Occasional Papers No. 7, Columbia University.

Ito, T. and T. Iwaisako, 1995. Explaining asset bubbles in Japan. NBER Working Paper No. 5358.

Kawata, J., 2011. The end of liberal democratic party-led-politics? From the point of view of political clientelism and corruption. Osaka University Law Review, 58: 1-26.

Kindleberger, C., 1978. Manias, panics, and crashes. A history of financial crises. New York: Basic Books.

Kubicova, I. and L. Komarek, 2011. The classification and identification of asset price bubbles. Czech Journal of Economics and Finance, 61(1): 34-49. View at Google Scholar

Masunaga, R., 1996. The deregulation process of foreign exchange control in capital transactions in post-war Japan. Revised Speech held at the State Planning Commission of China together with Yamaichi Securities Co. and held November 7/8, in Beijing.

Okina, K., 1999. Monetary policy under zero inflation: A response to criticisms and questions regarding monetary policy. Monetary and Economic Studies, 17(3): 157-200. View at Google Scholar

Okina, K., M. Shirakawa and S. Shiratsuka, 2000. The asset price bubble and monetary policy: Japan`s experience in the late $1980 \mathrm{~s}$ and the lessons. IMES Discussion Paper No. $2000-\mathrm{E}-12$.

Patrick, H., 1998. The causes of Japan's financial crisis. Paper Presented for the Conference on Financial Reform in Japan and Australia.

Pesaran, H.M. and Y. Shin, 1999. Autoregressive distributed lag modelling approach to cointegration analysis. In: S. Storm (Ed.), Econometrics and economic theory in 20th century: The Ragnar Frisch Centennial Symposium, Chapter 11, Cambridge University Press.

Remolona, E.M., 1993. The recent growth of financial derivative markets. FRBNY Quarterly Review, Winter 1992-93.

Satyajit, D., 2013. The setting sun - Japan's decline and fall. Wilmott, 65: 10-17.

Schnabl, G. and A. Hoffmann, 2007. Monetary policy, vagabonding liquidity and bursting bubbles in new and emerging markets - an overinvestment view. MPRA Paper No. 5201.

Shiller, R.J., 2000. Irrational excuberance. Princeton: Princeton University Press.

Shiller, R.S., F. Kon and Y. Tsutsui, 1992. Expanding the scope of expectations data collection: The U.S. and Japanese stock markets. Cowles Foundation Discussion Paper No.1012.

Shimizu, C. and T. Watanabe, 2010. Housing bubbles in Japan and the United States. Public Policy Review, 6(3): 431-472. View at Google Scholar

Tomfort, A., 2017. Crash und Geldflut - Wie die Notenbanken die nächste Krise heraufbeschwören. Wien: Goldegg-Verlag.

Uemura, H., 2009. Institutional change and growth regime in the Japanese economy: Faced by increasing International Interdependence with the Asian economies. Paper for the Annual Meeting of Japan Association for Evolutionary Economics.

Valev, N., 1996. International lending by U.S. Banks. Paper of the Center for International Business, Education and Research, Purdue University.

Weingarten, B., 2010. The cause of Japan`s boom and the reasons for its prolongued bust. LvM Working Paper.

Yoshino, N., T. Nakamura and Y. Sakai, 2012. Past crisis experience for Asia - banking behavior and the asset bubble. Preliminary Paper. 